\title{
High-resolution leaf wax carbon and hydrogen isotopic record of the late Holocene paleoclimate in arid Central Asia
}

\author{
B. Aichner ${ }^{1,2}$, S. J. Feakins ${ }^{1}$, J. E. Lee ${ }^{3}$, U. Herzschuh ${ }^{4,2}$, and X. Liu ${ }^{5}$ \\ ${ }^{1}$ Department of Earth Sciences, University of Southern California, Los Angeles, USA \\ ${ }^{2}$ Institute of Earth and Environmental Science, University of Potsdam, Potsdam, Germany \\ ${ }^{3}$ Department of Earth, Environmental and Planetary Sciences, Brown University, Providence, USA \\ ${ }^{4}$ Periglacial Research Unit, Alfred Wegener Institute Helmholtz Centre for Polar and Marine Research, Potsdam, Germany \\ ${ }^{5}$ College of Environmental Resources \& Tourism, Capital Normal University, Beijing, PR China \\ Correspondence to: B. Aichner (bernhard.aichner@gmx.de)
}

Received: 2 October 2014 - Published in Clim. Past Discuss.: 21 November 2014

Revised: 25 February 2015 - Accepted: 26 February 2015 - Published: 1 April 2015

\begin{abstract}
Central Asia is located at the confluence of largescale atmospheric circulation systems. It is thus likely to be highly susceptible to changes in the dynamics of those systems; however, little is still known about the regional paleoclimate history. Here we present carbon and hydrogen isotopic compositions of $n$-alkanoic acids from a late Holocene sediment core from Lake Karakuli (eastern Pamir, Xinjiang Province, China). Instrumental evidence and isotopeenabled climate model experiments with the Laboratoire de Météorologie Dynamique Zoom model version 4 (LMDZ4) demonstrate that $\delta D$ values of precipitation in the region are influenced by both temperature and precipitation amount. We find that these parameters are inversely correlated on an annual scale, i.e., the climate has varied between relatively cool and wet and more warm and dry over the last 50 years. Since the isotopic signals of these changes are in the same direction and therefore additive, isotopes in precipitation are sensitive recorders of climatic changes in the region. Additionally, we infer that plants use year-round precipitation (including snowmelt), and thus leaf wax $\delta D$ values must also respond to shifts in the proportion of moisture derived from westerly storms during late winter and early spring. Downcore results give evidence for a gradual shift to cooler and wetter climates between 3.5 and $2.5 \mathrm{cal} \mathrm{kyr}$ BP, interrupted by a warm and dry episode between 3.0 and $2.7 \mathrm{kyr}$ BP. Further cool and wet episodes occur between 1.9 and 1.5 and between 0.6 and $0.1 \mathrm{kyr}$ BP, the latter coeval with the Little Ice Age. Warm and dry episodes from 2.5 to 1.9 and 1.5 to $0.6 \mathrm{kyr} \mathrm{BP}$ coincide with the Roman Warm Period and Medieval Climate
\end{abstract}

Anomaly, respectively. Finally, we find a drying tend in recent decades. Regional comparisons lead us to infer that the strength and position of the westerlies, and wider northern hemispheric climate dynamics, control climatic shifts in arid Central Asia, leading to complex local responses. Our new archive from Lake Karakuli provides a detailed record of the local signatures of these climate transitions in the eastern Pamir.

\section{Introduction}

Future climate change associated with anthropogenic disturbance of the Earth system is expected to go hand in hand with changes in atmospheric circulation dynamics (Seth et al., 2011). In this scenario, certain regions of the globe are thought to be susceptible to severe and likely abrupt changes in moisture delivery and temperature. One example is Central Asia, located at the boundaries of influences from the midlatitude westerlies, the Siberian high and the limits of the Indian monsoon (Aizen et al., 2001; Chen et al., 2008). However, the nature and magnitude of changes in these climatic systems, as well as their Central Asian regional effects, are still poorly known. Detailed knowledge about past, naturally driven climatic variability in this region can contribute to a better understanding of the atmospheric dynamics behind those changes, which can in turn help to better predict possible impacts of future anthropogenically driven climate changes. 
While a large number of studies have analyzed climate dynamics in monsoonal eastern Asia and the north- and southeastern Tibetan Plateau (e.g., reviewed in Morill et al., 2003; An et al., 2006 and Herzschuh, 2006), the density of paleoclimate records in continental Central Asia remains comparably low. Central Asian records include studies of glacial extent in the Pamir (e.g., Narama, 2002a and b) and treering width reconstructions (e.g., Esper et al., 2002; Treydte et al., 2006). Lacustrine sedimentary archives exist from Kyrgyzstan (Ricketts et al., 2001; Lauterbach et al., 2014; Mathis et al., 2014), the Aral Sea (Sorrell et al., 2007a and b; Boomer et al., 2009; Huang et al., 2011), the western and southern Tarim Basin (Zhao et al., 2012; Zhong et al., 2007) and the Pamirs/Tajikistan (Mischke et al., 2010c; Lei et al., 2014; Fig. 1b). Only one of those studies has included compound-specific hydrogen isotopic analyses (Lauterbach et al., 2014), which have elsewhere in Asia shown the potential to provide information about moisture sources, precipitation amount and temperature (Mügler et al., 2010; Aichner et al., 2010c; Liu et al., 2008).

Climatic patterns in Central Asia are complex due to the above-mentioned location on the boundary between various large-scale atmospheric circulation systems, as well as the varied topography of the area (Fig. 1). While the easternmost parts are generally arid and receive most of their precipitation during the summer, western regions receive a higher proportional input from westerly-derived winter precipitation (Miehe et al., 2001; Machalett et al., 2008; Lauterbach et al., 2014). Thus, a dense network of paleoclimatic records is required to fully understand spatial patterns of climate dynamics over time.

To further decipher past climatic processes in our study, we generated a high-resolution, mid- to late Holocene paleoclimatic record from Lake Karakuli (western China), located in the eastern Pamir, at the very westernmost edge of the Tibetan Plateau. Building upon the work of Liu et al. (2014), who inferred glacial fluctuations from grain-size parameters and elemental composition at the same lake, we use compound-specific carbon $\left(\delta^{13} \mathrm{C}\right)$ and hydrogen $(\delta D)$ isotopic compositions of long-chain $\left(>\mathrm{C}_{24}\right) n$-alkanoic acids originating from plant leaf waxes to deduce past climatic changes in our study area. To evaluate the hydrogen isotopic data, it is essential to understand what drives the variability in the isotopic signal which is recorded by the biomarkers in a specific study area. Therefore, we draw comparisons to isotope-enabled model experiments using the Laboratoire de Météorologie Dynamique Zoom model version 4 (LMDZ4) simulations (Hourdin et al., 2006; Risi et al., 2010, 2012a and b; Lee et al., 2012). On the basis of these data, we characterize the processes controlling the isotopic composition of precipitation over Central Asia and discuss the implications for the interpretation of the biomarker isotopic evidence.

\section{Study site}

Lake Karakuli (also known as Lake Kala Kule) is a small lake (ca. $1 \times 1.5 \mathrm{~km}$ ) located at the westernmost edge of Xinjiang Province (PR China) at an altitude of $3650 \mathrm{~m}$, between the massifs of Kongur Shan and Muztagh Ata, both exceeding $7500 \mathrm{~m}$ (Fig. 1a). Those mountains which form the eastern edge of the Pamir Plateau and the very westernmost edge of the Tibetan Plateau are directly adjacent to the ranges of Karakorum and Tien Shan. The climate in this high-altitude region is cold and dry. At Taxkorgan climate station, $80 \mathrm{~km}$ south of Lake Karakuli (3090 m), average annual temperatures and precipitation amounts are $3.2^{\circ} \mathrm{C}$ and $69 \mathrm{~mm}$, respectively (1957-1990; Miehe et al., 2001), with June and July being the wettest months. Climatic data from Bulun Kul $(3310 \mathrm{~m}), 30 \mathrm{~km}$ north of our study area, are in a similar range $\left(0.6^{\circ} \mathrm{C}\right.$ and $\left.127 \mathrm{~mm}\right)$, with a precipitation maximum during spring and summer (1956-1968; Miehe et al., 2001). At higher altitudes, precipitation amounts increase by orographic forcing. At the Muztagh Ata, annual rain- and snowfall was estimated to account for about $300 \mathrm{~mm}$ at the glacier accumulation zone (at $5919 \mathrm{~m}$; Seong et al., 2009a), while other studies estimated a water equivalent depth of $605 \mathrm{~mm}$ for snow accumulation at $7010 \mathrm{~m}$ (Wu et al., 2008).

Lake Karakuli is an open freshwater lake with a maximum depth of $20 \mathrm{~m}$. The relatively small catchment comprises meltwater mainly derived from glaciers on the western flank of Mt Muztagh Ata. These form an alluvial fan with several creeks which discharge into the lake from the south, while the single outflow drains towards the north (see Fig. 1 and S1 in the Supplement). Most of the glacial runoff derived from the surrounding massifs, including the main glacier of Muztagh Ata and Mt Kongur Shan, does currently not discharge into the lake.

The sparse vegetation consists of alpine grasslands, partly used for pasture (see Fig. S1), with an alpine desert at higher altitudes. Above $5500 \mathrm{~m}$ the landscape is fully glaciated (with valley glaciers descending to $4300 \mathrm{~m}$; Tian et al., 2006). Compared to other shallow lakes on the Tibetan Plateau, where macrophytes are numerous (Aichner et al., 2010b), there are only a few emergent and submerged macrophytes on or close to the shores and few indications for submerged plants in the deeper parts of the lake.

\section{Material and methods}

\subsection{Coring and chronology}

A sediment core with a composite length of ca. $820 \mathrm{~cm}$ was taken in September 2008 at $38.43968^{\circ} \mathrm{N}$ and $75.05725^{\circ} \mathrm{E}$ from a water depth of $16 \mathrm{~m}$, using an UWITEC coring system and a floating platform (the coring position is shown in the Supplement S7). The chronology was based on 17 radiocarbon ages derived from ${ }^{14} \mathrm{C}$ AMS (accelerator mass spectrom- 

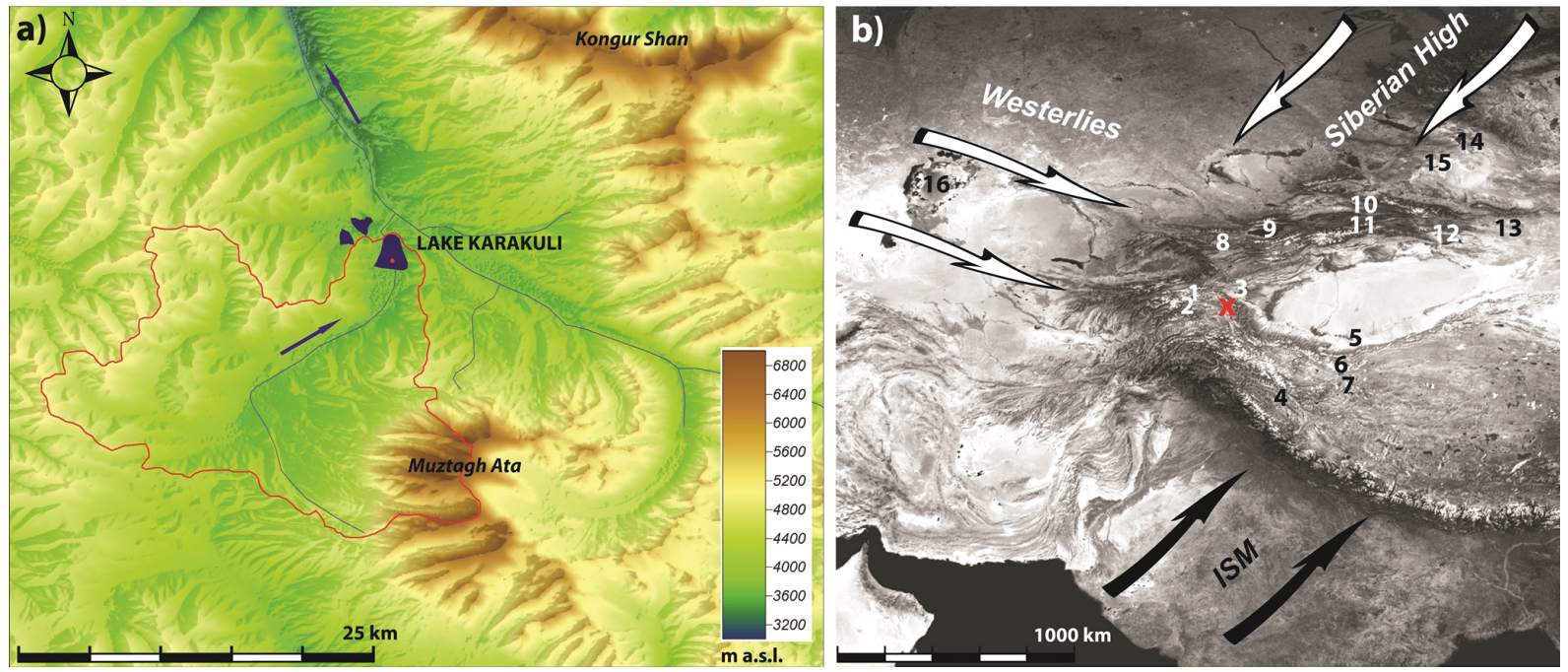

Figure 1. (a) Catchment of Lake Karakuli and coring position (red dot). (b) Location of our study area (red cross) and other paleoclimatic records mentioned in the text. 1: large Lake Karakul, Tajikistan (Mischke et al., 2010); 2: Lake Sasi Kul (Lei et al., 2014); 3: Kashgar (Zhao et al., 2012); 4: Tso Kar (Wünnemann et al., 2010); 5: southern Tarim Basin (Zhong et al., 2007); 6: Guliya Ice Core (e.g., Thompson et al., 1997); 7: Lake Bangong (Gasse et al., 1996); 8: Son Kol (Lauterbach et al., 2014; Mathis et al., 2014), 9: Issyk Kul (Ricketts et al., 2001); 10: Yili section (Li et al., 2011); 11: Kesang Cave (Cheng et al., 2012); 12: Boston Hu (Wünnemann et al., 2006); 13: Lake Balinkun (An et al., 2012); 14: Ulungur Hu (Liu et al., 2008); 15: Lake Manas (Rhodes et al., 1996); 16: Aral Sea (Sorrell et al., 2007a and b; Boomer et al., 2009; Huang et al., 2011).

etry) dating conducted on total organic carbon (TOC, Liu et al., 2014). The 0 cal. year BP (1950 AD) was derived from ${ }^{210} \mathrm{~PB} /{ }^{137} \mathrm{Cs}$ dating and appeared at ca. $10.5 \mathrm{~cm}$ depth. A reservoir effect of 1880 years was extrapolated from the dating of core-top samples and assumed to be constant throughout the core. The ${ }^{14} \mathrm{C}$ ages indicate a nearly constant sedimentation rate across 4.2 kyrs. For the calibration of the ages and construction of the age-depth model, the IntCal09 data set was used (Reimer et al., 2009) applying a Bayesian method (Blaauw and Christen, 2011); for details see Liu et al. (2014).

\subsection{Lab chemistry}

Sediments were extracted with an Accelerated Solvent Extraction system (ASE 350; Dionex, Sunnyvale, USA), under high pressure $(1500 \mathrm{psi})$ and temperature $\left(100^{\circ} \mathrm{C}\right)$ and using $\mathrm{DCM} / \mathrm{MeOH}(9: 1)$ as a solvent. Alkanoic acids were separated from the total lipid extract using column chromatography $\left(5 \mathrm{~cm} \times 40 \mathrm{~mm}\right.$ Pasteur pipette, $\mathrm{NH}_{2}$ sepra bulk packing, $60 \AA$ ) and eluting with $2: 1 \mathrm{DCM} /$ isopropanol, followed by $4 \%$ formic acid in diethylether, which yielded neutral and acid fractions, respectively. The acid fraction was esterified with $5 \% \mathrm{HCl}$ and $95 \%$ methanol (of known isotopic composition) at $70^{\circ} \mathrm{C}$ for $12 \mathrm{~h}$ to yield corresponding fatty acid methyl esters (FAMEs). Lipids were obtained by liquidliquid extraction, using hexane as the nonpolar solvent, and dried by passing through a column of anhydrous $\mathrm{Na}_{2} \mathrm{SO}_{4}$. They were further purified using column chromatography
$(5 \mathrm{~cm} \times 40 \mathrm{~mm}$ Pasteur pipette, $5 \%$ water-deactivated silica gel, 100-200 mesh) and eluting with hexane, followed by FAMEs eluted with DCM.

\subsection{Biomarker isotopic analysis}

Compound-specific isotopic values were obtained using gas chromatography isotope ratio mass spectrometry (GCIRMS). We used a Thermo Scientific ${ }^{\circledR}$ Trace gas chromatograph equipped with an Rxi-5ms column $(30 \mathrm{~m} \times 0.25 \mathrm{~mm}$, film thickness $1 \mu \mathrm{m}$ ) and a programmable temperature vaporizing (PTV) injector operated in solvent split mode with an evaporation temperature of $60^{\circ} \mathrm{C}$. The $\mathrm{GC}$ was connected via a GC Isolink with pyrolysis/combustion furnace (at $1400 / 1000^{\circ} \mathrm{C}$ ) and a Conflo IV interface to a DeltaV $V_{\text {Plus }}$ isotope ratio mass spectrometer. The $\mathrm{H}_{3}^{+}$factor (Sessions et al., 2001) was determined daily to test measurement linearity of the system and accounted for $5.8 \mathrm{ppm} \mathrm{mv}^{-1}$ on average. Reference peaks of $\mathrm{H}_{2} / \mathrm{CO}_{2}$ bracket $n$-alkanoic acid peaks during the course of a GC-IRMS run; two of these peaks were used for the standardization of the isotopic analysis, while the remainders were treated as unknowns to assess precision. Except for the case of co-elution, precision of these replicates was better than $0.6 \%$.

Data were normalized to the Vienna Standard Mean Ocean Water (VSMOW)-Standard Light Antarctic Precipitation (SLAP) hydrogen isotopic scale and to the Vienna Pee Dee Belemnite (VPBD) carbon isotopic scale by comparing them with an external standard containing $15 n$ - 
alkane compounds $\left(\mathrm{C}_{16}\right.$ to $\left.\mathrm{C}_{30}\right)$ of known isotopic composition (obtained from A. Schimmelmann, Indiana University, Bloomington). The root mean square error of replicate measurements of the standard across the course of analyses was below 5\%o (hydrogen) and $0.7 \%$ (carbon). For hydrogen isotopes we further monitored for instrument drift by measuring the $\delta D$ values of a $\mathrm{C}_{34} n$-alkane internal standard co-injected with the sample $(-240.6 \pm 3.0 \%$; $n=105)$. The isotopic composition of $\mathrm{H}$ and $\mathrm{C}$ added during methylation of alkanoic acids was estimated by methylating and analyzing phthalic acid as a dimethyl ester (isotopic standard from A. Schimmelmann, University of Indiana), yielding $\delta D_{\text {methanol }}=-198.3 \pm 3.9 \%$ and $\delta^{13} \mathrm{C}_{\text {methanol }}=-25.45 \pm 0.42 \%$ o $(n=7)$. Correction for $\mathrm{H}$ and $\mathrm{C}$ added by methylation was then made by way of mass balance.

\subsection{LMDZ4 simulations}

To understand the control of spatial and seasonal isotopic variations, we use the climate model LMDZ4 (Hourdin et al., 2006) to characterize the processes controlling isotopes of precipitation over our study area. Details of the model and methodology are described in Risi et al. (2010, 2012a and b) and Lee et al. (2012). Briefly, the applied model version incorporates the entire cycle of stable water isotopes and includes fractionation when phase changes occur. The resolution of the model is $2.5^{\circ} \times 3.75^{\circ}$, with 19 vertical levels in the atmosphere. To obtain more realistic simulations of the hydrology and isotope values compared to free-running simulations and to better reproduce the observed circulation pattern, simulated winds from LMDZ4 are relaxed toward the pseudo-observed horizontal wind field from the ERA-40 reanalysis results (Uppala et al., 2005) with a time constant of $1 \mathrm{~h}$. Boundary conditions used observed sea surface temperatures and sea ice fractions from the HadISST (Hadley Centre Sea Ice and Sea Surface Temperature) data set (Rayner et al., 2003) from 1958 to 2009.

\section{Results}

\subsection{Lipid concentrations}

Due to the sparse vegetation in and around the lake, concentrations of leaf wax biomarkers in the sediments were relatively low. For compound-specific isotopic analysis, we chose fatty acids (FAs), which showed higher concentrations than alkanes in a set of test samples. Here, $\mathrm{C}_{24}, \mathrm{C}_{26}$ and $\mathrm{C}_{28} n$-alkanoic acids were the most abundant compounds, which average concentrations of ca 1050, 1000 and $750 \mathrm{ng} \mathrm{g} \mathrm{dw}^{-1}$ (nanograms per grams dry weight; Fig. S2 in the Supplement). We found that fatty acid concentrations were relatively constant with depth, suggesting no major change in productivity, dilution or preservation during the late Holocene.

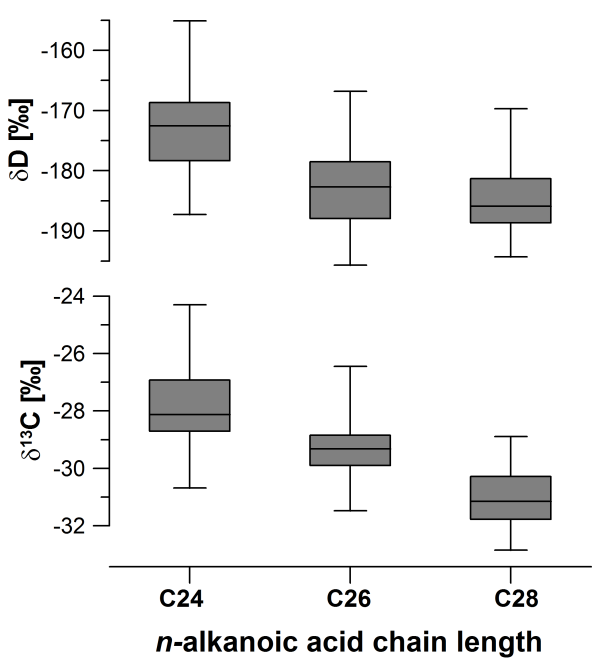

Figure 2. Box and whisker plots of $\delta D$ and $\delta^{13} \mathrm{C}$ values in sediment samples by chain length.

\section{2 $\delta D$ and $\delta^{13} \mathrm{C}$ values of leaf wax lipids and water samples}

In total, we measured 125 core samples for hydrogen isotopic composition and 66 samples for carbon isotopic composition (S6 in the Supplement). Samples contained $\mathrm{C}_{16^{-}}$ $\mathrm{C}_{28} n$-alkanoic acids with an even-odd chain length preference. We report isotopic results for the $\mathrm{C}_{24}, \mathrm{C}_{26}$ and $\mathrm{C}_{28}$ $n$-alkanoic acids, as these are target long-chain compounds within the dynamic range of isotopic measurement capabilities (S6, Fig. S3 in the Supplement).

$\delta^{13} \mathrm{C}$ values are generally more depleted with increasing chain length, with $\mathrm{C}_{24}$ averaging $-27.9 \pm 1.4 \%$ o, $\mathrm{C}_{26}$ averaging $-29.3 \pm 1.0 \%$ and $\mathrm{C}_{28} n$-alkanoic acids averaging $-31.0 \pm 0.9 \%$ (Figs. 2 and S3). For $\mathrm{C}_{28}$ we find no significant downcore trend. $\mathrm{C}_{24}$ shows the largest variations in $\delta^{13} \mathrm{C}$ values with generally more ${ }^{13} \mathrm{C}$-depleted values in the middle of the core (min: $-30.7 \%$ ) compared to the core base and core top (max: $-24.3 \%$; Fig. S3). For hydrogen isotopes, compounds are also more D-depleted with increasing chain length $\left(\mathrm{C}_{24}:-173 \pm 6 \%\right.$; $\mathrm{C}_{26}$ : $-182 \pm 7 \%$; $\mathrm{C}_{28}$ : $-185 \pm 6 \%$; Fig. 2). We observe downcore variations in $\delta D$ values for $C_{26}$ and $C_{28}$ ranging from -196 to $-167 \%$.

Six water samples (two from inflows, two from Lake Karakuli and two from ponds nearby) have been analyzed for isotopic composition (Table 1). Both inflows show similar isotopic signatures (ca. $-83 \%$ ). The lake water averages $+3.5 \% \circ\left(\delta^{18} \mathrm{O}\right)$ and $+15 \%$ o $(\delta D)$, enriched relative to the inflow due to evaporation. Closed ponds nearby are also evaporatively enriched relative to inflow. 
Table 1. $\delta^{18} \mathrm{O}$ and $\delta D$ values of water samples collected in September 2008 at Lake Karakuli, its inflows and nearby ponds.

\begin{tabular}{|c|c|c|c|c|c|c|c|}
\hline $\begin{array}{l}\text { Latitude } \\
{\left[{ }^{\circ} \mathrm{N}\right]}\end{array}$ & $\begin{array}{l}\text { Longitude } \\
{\left[{ }^{\circ} \mathrm{E}\right]}\end{array}$ & $\begin{array}{l}\text { Altitude } \\
{[\mathrm{m}]}\end{array}$ & Description & $\begin{array}{r}\delta^{18} \mathrm{O} \\
{[\% o]}\end{array}$ & $1 \sigma$ & $\begin{array}{r}\delta D \\
{[\% o]}\end{array}$ & $1 \sigma$ \\
\hline 38.41933 & 75.05995 & 3684 & inflow1 & -12.1 & 0.05 & -83.2 & 0.2 \\
\hline 38.42021 & 75.05008 & 3688 & inflow2 & -12.1 & 0.01 & -84.4 & 0.2 \\
\hline 38.43968 & 75.05725 & 3657 & Karakuli - core position surface water & -9.4 & 0.04 & -67.8 & 0.2 \\
\hline 38.43968 & 75.05725 & 3657 & Karakuli - core position above sediment & -9.2 & 0.03 & -67.2 & 0.2 \\
\hline 38.46294 & 75.02928 & 3658 & pond near Karakuli & 5.45 & 0.02 & 13.5 & 0.4 \\
\hline 38.46334 & 75.04267 & 3676 & pond near Karakuli & -3.6 & 0.02 & -37.1 & 0.5 \\
\hline
\end{tabular}

\section{Discussion}

\subsection{Origin of organic compounds and implications for source water}

\subsubsection{Molecular abundance distribution}

Organic compounds in lake sediments originate from a mixture of terrestrial and aquatic organisms, with molecular abundance distributions and isotopic compositions that may be diagnostic of source. Most plants contain a broad range of biomarkers (e.g., $n$-alkanes or fatty acids), but the fingerprints of the different compound classes are often dominated by compounds of a specific chain length. Terrestrial and emergent aquatic plants, for instance, produce higher proportional abundances of long-chain $n$-alkanes (e.g., $\mathrm{C}_{29}$ and $\mathrm{C}_{31}$ ), while submerged macrophytes contain higher amounts of mid-chain $n$-alkanes (e.g., $\mathrm{C}_{23}$ and $\mathrm{C}_{25}$ Ficken et al., 2000; Aichner et al., 2010b). $n$-Alkanoic acids show a less distinct pattern (Ficken et al., 2000), but long-chain compounds (e.g., $\mathrm{C}_{28}$ FAs) are mostly interpreted as originating from terrestrial sources here as well (e.g., Kusch et al., 2010; Feakins et al., 2014).

In the sediments of Lake Karakuli, the contribution of aquatic plants to the lipid pool is considered to be relatively low compared to other Tibetan high-altitude lakes. A submerged aquatic plant sample collected close to the shoreline (ca. $20 \mathrm{~cm}$ water depth) shows a dominance of $\mathrm{C}_{16}$ and $\mathrm{C}_{18}$ FAs and minor relative amounts of $\mathrm{C}_{20}$ to $\mathrm{C}_{30}$ evenchain FAs (see Fig. S4 in the Supplement). This fatty-acid pattern is in agreement with published fingerprints of other aquatic plants collected on the Tibetan Plateau (Wang and Liu, 2012). Hence, the low relative abundance of $C_{16}$ and $C_{18}$ FAs in our sediment samples suggests a relatively low contribution of plant material derived from aquatic macrophytes to the sedimentary organic matter in Lake Karakuli.

\subsubsection{Carbon isotopic signal}

An additional indication for the source of compounds comes from their carbon isotopic signature. Lipids of terrestrial $\mathrm{C}_{3}$ plants usually show values around -30 to $-35 \%$, while compounds derived from terrestrial $\mathrm{C}_{4}$ plants and from sub- merged aquatic macrophytes can reach significantly higher values, in the range of -15 to $-20 \%$ (Chikaraishi and Naraoka, 2005; Aichner et al., 2010a). The difference between $\mathrm{C}_{3}$ and $\mathrm{C}_{4}$ plants can be explained by different isotopic fractionation in the carbon assimilation of those two plant types, while the higher values of submerged aquatic plants are due to the uptake of different carbon sources, i.e., isotopically enriched bicarbonate instead of dissolved $\mathrm{CO}_{2}$ (Allen and Spence, 1981; Prins and Elzenga, 1989).

In our sediment core from Lake Karakuli, $\delta^{13} \mathrm{C}$ values of the $\mathrm{C}_{28} \mathrm{FA}$ are similar to that of terrestrial $\mathrm{C}_{3}$ plants without a clear trend (Fig. 2; S3). Thus, we conclude that this compound is predominantly derived from terrestrial $\mathrm{C}_{3}$ grasses in the lake catchment. $\delta^{13} \mathrm{C}$ values of $\mathrm{C}_{24}$ and $\mathrm{C}_{26} n$-alkanoic acids are slightly higher than for $\mathrm{C}_{28}$, indicating an increasing contribution of submerged aquatic plant material and/or lipids derived from $\mathrm{C}_{4}$ plants with decreasing chain lengths.

$\delta^{13} \mathrm{C}$ values of $\mathrm{C}_{24} n$-alkanoic acids are controlled by relative contributions of aquatic macrophytes and/or macrophyte productivity, with higher productivity leading to higher $\delta^{13} \mathrm{C}$ values (Aichner et al., 2010b). We hypothesize that a higher proportional input of aquatic material to the sedimentary organic matter is indicative of warmer and possibly also drier conditions. Longer ice-free periods and a lower lake level could be the driving factors behind enhanced macrophyte growth during warmer years.

$\mathrm{C}_{4}$ plants are widely absent on the central and eastern Tibetan Plateau at present, but they are widespread in Central Asian deserts and some Chenopodiaceae which use the $\mathrm{C}_{4}$ pathway have occasionally been observed in high-altitude alpine deserts of the Pamir (Sage et al., 2011). Thus, we cannot totally exclude the contribution of $\mathrm{C}_{4}$-derived lipids to the sedimentary organic matter of Lake Karakuli; however, we consider these sources to be of secondary importance. Nevertheless, if we underestimated the input of alkanoic acids derived from $\mathrm{C}_{4}$ plants, this would not bias the overall interpretation because higher abundances of $\mathrm{C}_{4}$ plants resulting in higher sedimentary $\delta^{13} \mathrm{C}$ would indicate a drier and warmer climate, which is similar to the hypothesis that drying and warming leads to increased macrophyte productivity. 


\subsubsection{Hydrogen isotopic signal}

Hydrogen isotopes provide further evidence for the origins of $\mathrm{C}_{24}$ and $\mathrm{C}_{26}$ or $\mathrm{C}_{28} n$-alkanoic acids. The average $\delta D$ values of $\mathrm{C}_{24}$ are ca. $9-12 \%$ o higher than those of $\mathrm{C}_{26}$ and $\mathrm{C}_{28}$ (Fig. 2). A different water source, i.e., isotopically enriched lake water (see Table 1) instead of water derived from precipitation or snowmelt, could explain this. We assume that $\mathrm{C}_{24}$ is derived from mixed aquatic and terrestrial sources, while $\mathrm{C}_{28}$ and also $\mathrm{C}_{26}$ can be considered to be of mainly terrestrial origin.

The $\delta D$ values of these terrestrial biomarkers are representative of the hydrogen isotopic composition of the source water. For terrestrial plants this could be expected to be spring and summer precipitation during the growing season (Sachse et al., 2012), although a contribution of $D$-depleted meltwater from snow in the early spring growth period is highly likely (Fan et al., 2014). The fractionation factors between source water and lipids are variable, but previous studies found that for terrestrial $\mathrm{C}_{3}$ grasses they average $-149 \pm 28 \%$ o $(n=47)$ for the $\mathrm{C}_{29} n$-alkane, while they are ca. $-134 \pm 28 \%$ o $(n=53)$ for $\mathrm{C}_{4}$ grasses and in a similar range for forbs (Sachse et al., 2012). In arid ecosystems, soilwater evaporation (for grasses; Smith and Freeman, 2006) and transpiration from the leaf, lead to isotopic enrichment of leaf water above the meteoric water (Feakins and Sessions, 2010; Kahmen et al., 2013a and b). Recent results from the central Tibetan Plateau, a similar environmental setting to our study, quantified the apparent isotopic fraction between meteoric water and $n$-alkanes as being ca. $-95 \%$ o due to ca. $+70 \%$ evapotranspirational isotopic enrichment above meteoric water (Günther et al., 2013). This is in agreement with the average fractionation from Feakins and Sessions (2010), who suggested ca. $-95 \%$ as a net fractionation factor between meteoric water and leaf wax $n$-alkanes in an arid ecosystem (southern California) and found similar values for $n$-alkanoic acids in a later study from that region (Feakins et al., 2014).

While the fractionation was not directly determined on modern plant $n$-alkanoic acids in this catchment, based on core-top $\delta D_{\text {lipid }}$ values of ca. $-190 \%$ and a knowledge of hydrogen isotope values of modern precipitation and waters in the catchment, we can infer a reasonable catchment average apparent fractionation (Fig. 3). Summer precipitation in the catchment averages ca. $-45 \%$ at Lake Karakuli, compared to a mean annual precipitation average of ca. $-90 \%$ o (derived from the Online Isotopes in Precipitation Calculator, OIPC; Bowen and Revenaugh, 2003; Fig. 4b). If the summer precipitation is indicative of source water, and given the measured sedimentary value of $\mathrm{C}_{28} n$-alkanoic acids $(-190 \%)$, we would compute an apparent fractionation of ca. $-150 \%$ o (Fig. 3; see the Supplement S5 for formula to calculate isotopic fractionation factors). Whereas if we use mean annual precipitation, then the calculated apparent fractionation would be ca. $-110 \%$, which is closer to the reported frac-

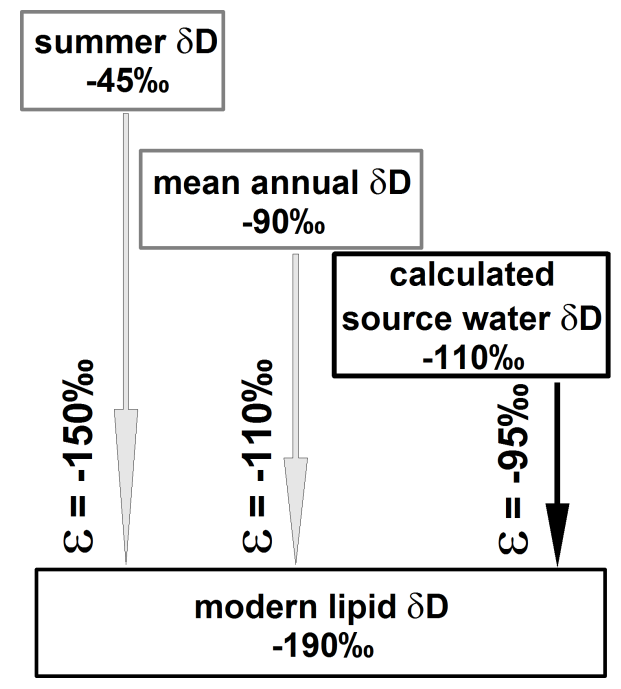

Figure 3. Calculated isotopic fractionation factors $(\varepsilon)$ between summer and mean annual precipitation and modern lipids, as well as calculated source water $\delta D$ based on published fractionation factors in arid ecosystems (ca. $-95 \%$, according to Feakins and Sessions, 2010; Günther et al., 2013).

tionation factors for arid ecosystems (Feakins and Sessions, 2010; Günther et al., 2013).

The $\delta D$ values of the two lake inflows sampled in September 2008 (average $-83 \%$; Table 1) provide a reasonable constraint on catchment average water isotopic composition in September, presumably including a mix of contributions from precipitation runoff, groundwater and snowmelt from winter precipitation and higher elevations. A calculated source water $\delta D$ value based on published fractionation factors mentioned above (ca. $-95 \%$ ) would be $-110 \%$ (Fig. 3) which is in the range of late-winter and early-spring precipitation in the study area according to OIPC data (Fig. 4b). These are helpful constraints on the proxy; however, regardless of knowing the exact season of source water and the appropriate fractionation which are needed for absolute isotopic conversions, we can infer relative variations in $\delta D$ values of the $\mathrm{C}_{28} n$-alkanoic acid downcore from variations in the $\delta D$ of precipitation. We therefore use the $\delta D$ values of the $\mathrm{C}_{28}$ and $\mathrm{C}_{26} n$-alkanoic acids to reconstruct past variations in the isotopic composition of precipitation.

\subsection{Controls on the isotopic signature of precipitation in the eastern Pamir}

\subsubsection{Monthly signal}

The isotopic composition of precipitation is influenced by multiple isotope effects including those associated with precipitation amount, condensation temperature or vapor source (Gat, 1996). In subtropical and tropical latitudes, the "amount effect" has usually been identified as the most relevant controlling factor, with lower $\delta D$ values reflecting 


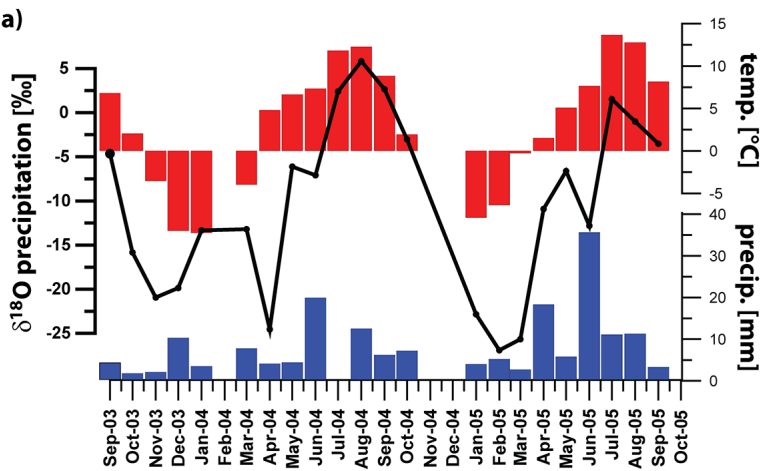

b)

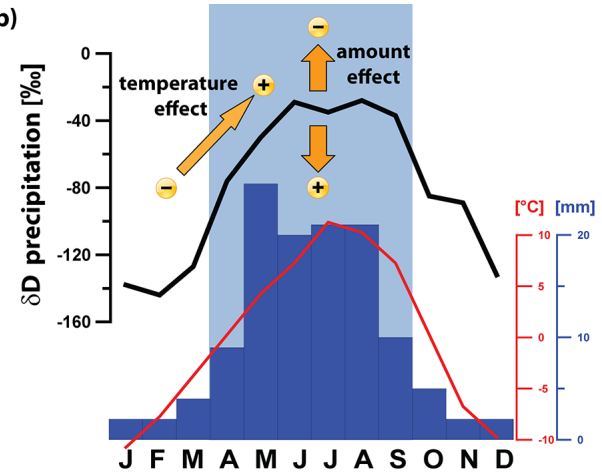

Figure 4. (a) Monthly isotopic and climate data from Taxkorgan climate station (Yao et al., 2013), located ca. $80 \mathrm{~km}$ south of Lake Karakuli (altitude ca. $3100 \mathrm{~m}$ ). (b) Average monthly climate (Miehe et al., 2001) and isotopic (OIPC; Bowen and Revenaugh, 2003) data from Bulun Kul climate station, located ca. $30 \mathrm{~km}$ northeast of Lake Karakuli (altitude ca. $3300 \mathrm{~m}$ ). Shaded area indicates summer, i.e. wet season.

more humid episodes in sedimentary records (Schefuss et al., 2005; Tierney et al., 2008, Lee and Fung, 2008). At mid- and high latitudes, temperature and vapor sources have mostly been interpreted as being the dominant factors (Dansgaard, 1964; Thompson, 2000; Rach et al., 2014). In addition, largescale circulation changes or a shift in the balance of two or more different moisture sources and transport trajectories can result in isotopic shifts over time (Dansgaard, 1964; Thompson, 2000; Rach et al., 2014).

By evaluating isotopes of precipitation in the context of climatic parameters in Asia, Araguas-Araguas et al. (1998) and Yao et al. (2013) came to the conclusion that the amount effect is the dominant factor in monsoonal east Asia, while in arid Central Asia temperature mainly controls $\delta D$ and $\delta^{18} \mathrm{O}$ values of precipitation. The closest meteorological stations to Lake Karakuli are the station at Bulun Kul (ca. $30 \mathrm{~km}$ northeast) and Taxkorgan (ca. $80 \mathrm{~km}$ south). Both stations record low winter precipitation and slightly enhanced amounts during the summer (Fig. 4a and b). Higher isotopic values in the summer compared to the winter (Yao et al., 2013; Bowen and Revenaugh, 2003) suggest that monthly values are indeed driven by temperature. If these seasonal controls also determine interannual variations in the isotopic composition of precipitation then temperature is likely to be a major factor explaining the reconstructed hydrogen isotopic variability.

We also observe amount effect modulation of the summer season precipitation isotopes associated with increased precipitation totals in June 2004 and - to a greater extent in June 2005 (Fig. 4a), which lowers the $\delta^{18} \mathrm{O}$ values. This amount effect lowers the summer precipitation isotopic composition, dampens the seasonality of the mean precipitation of isotopic values and lowers the integrated annual precipitation isotopic composition. Hence, in drier years average $\delta D$ values will be $D$-enriched relative to wetter years, and likewise warmer years will be $D$-enriched relative to colder years (Fig. 4b). Given the low precipitation amounts in this arid region today, the amount effect is likely to remain sec- ondary to the temperature controls on isotopic composition apparent in the seasonal cycle.

\subsubsection{Annual and seasonal signal}

To further establish the connections between climate anomalies and isotopic signatures of precipitation in Central Asia, we compare instrumental data and climate model simulations. At Taxkorgan meteorological station, we find a negative correlation between annual temperature and the precipitation amount over a period of 44 years (1957-2000; Fig. 5; data provided from Tian at al., 2006). Similar trends can be observed when comparing simulated data over a period of 52 years (1958-2009; Fig. 5). We use the LMDZ4 climate model (Hourdin et al., 2006) to characterize the climatic processes in our study area (as described in Lee et al., 2012). We find higher annual precipitation amounts in the LMDZ4 model simulations compared to instrumental observations at Taxkorgan meteorological stations. This is related to the scale of the model resolution of $3.75^{\circ} \times 2.5^{\circ}$ (Lee et al., 2012), which includes the relatively high precipitation amounts in higher altitudes during winter (Seong et al., 2009a and b; Wu et al., 2008) within the grid box. Significant negative correlations $(r=0.58 ; p<0.0001)$ between temperature and precipitation amount can be inferred for the summer months (April-September), while comparisons over the winter or whole year deliver nonsignificant correlations ( $p>0.01$; Fig. 5).

As a consequence of the negative correlation between temperature and precipitation amount, we observe positive and negative correlations between precipitation isotopes and those climatic parameters for our larger study area (Fig. 6). Considering temperature, we found a positive correlation $(0.4<r<0.6)$ for both winter and summer over large parts of Central Asia. For the summer, no correlations are seen in India and SE Asia, where distinct monsoonal circulation and precipitation patterns exert independent controls on the isotopic values of precipitation (Morill et al., 2003; Yao et 

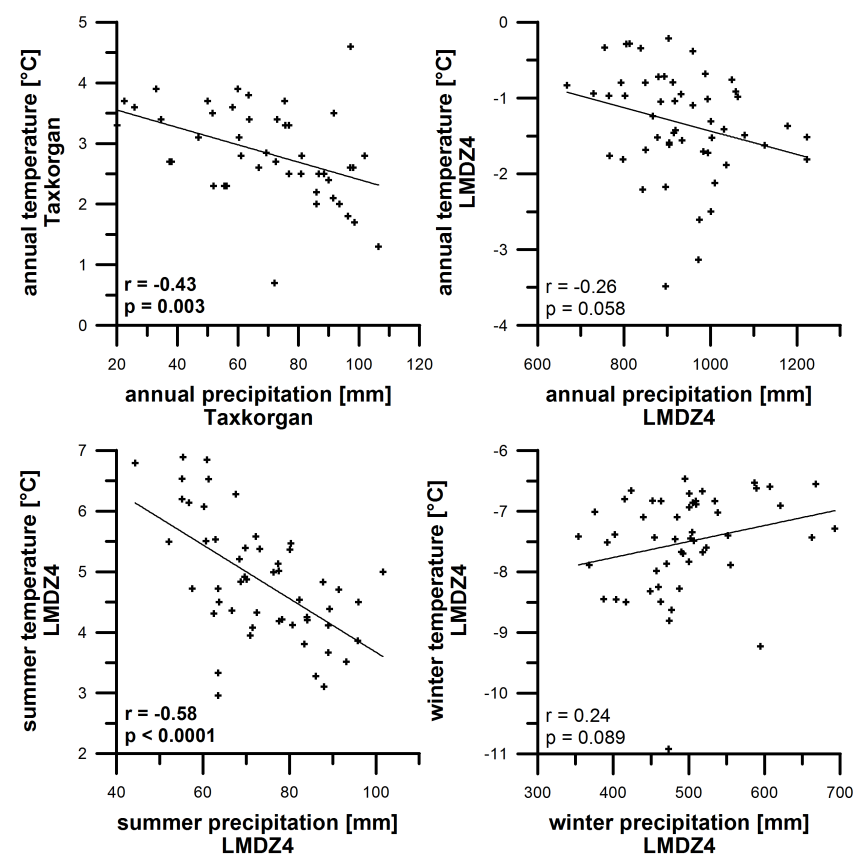

Figure 5. Correlations of temperatures with precipitation amounts based on instrumental data from Taxkorgan meteorological station (1957-2000; annual averages) and model data using LMDZ4 simulations (1958-2009; summer: April-September; winter: OctoberMarch). Bold correlation coefficients are significant at the 0.01 level.

al., 2013). Considering precipitation amount, negative correlations $(-0.6<r<-0.2)$ can be deduced for the summer months for a large region around Lake Karakuli, from SW to NE and covering parts of Iran, Central Asia and NW China. During winter, no correlation can be observed directly at the location of the lake; however, precipitation isotopes seem to negatively correlate with precipitation amounts located west of our study area (Fig. 6).

In a recent study, Tian et al. (2006) found a positive correlation between $\delta^{18} \mathrm{O}$ in the local Muztagh Ata ice core (which covers the period 1957-2003) and annual temperatures from Taxkorgan climate station. In contrast, they found no significant relationship between ice core $\delta^{18} \mathrm{O}$ and annual precipitation amounts at Taxkorgan (Tian et al., 2006). Different precipitation dynamics between middle and high altitudes and/or seasonal differences, as supported by our LMDZ4 data, could explain this discrepancy. Elevation differences may play a role in different precipitation patterns, and these may be associated with isotope effects. The Muztagh Ata glacier accumulation zone receives higher annual precipitation amounts and also a higher proportional input from winter precipitation compared to lower altitudes (Seong et al., 2009a and b). Whilst instrumental and modeling data inferred a slight increase of precipitation amount throughout the last 50 years in the westernmost part of China (Yao et al., 2012; Zhang and Cong, 2014), a decreasing accumulation
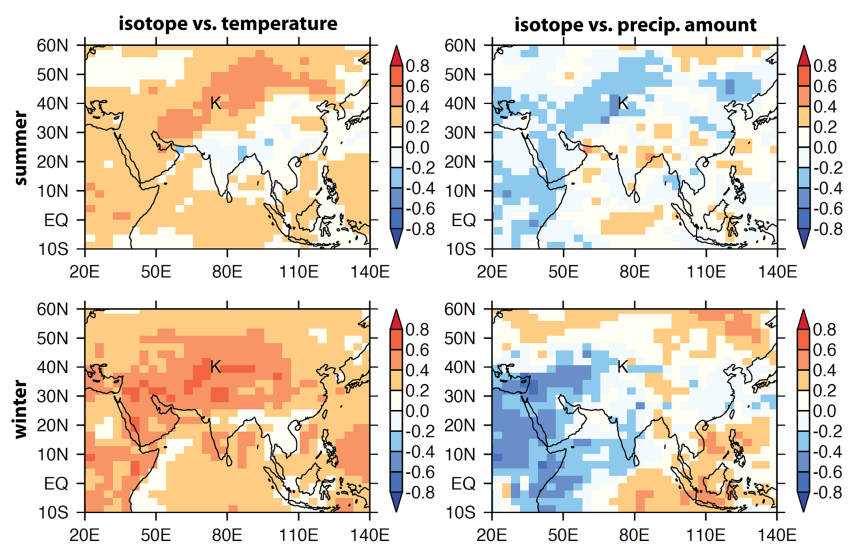

Figure 6. Spatial correlation coefficients $(r)$ of summer (AprilSeptember) and winter (October-March) $\delta^{18} \mathrm{O}_{\text {precip }}$ at the Karakuli site (marked as $K$ in the plots) with temperatures and precipitation amounts at each grid point from 1958 to 2009 (LMDZ4 simulations; Lee et al., 2012).

rate at the Muztagh Ata ice core since 1976 was measured by Duan et al. (2007). Even if the instrumental data from Taxkorgan do not show a significant trend in precipitation amounts between 1957 and 2000, this does not rule out changes of snowfall at higher altitudes. Increasing temperatures could have further contributed to the lower observed accumulation rates.

Since temperature and precipitation amounts are anticorrelated on an interannual timescale (Fig. 5), we interpret low $\delta D$ values to indicate both relatively cool and wet conditions. In addition to fluctuations in mean annual precipitation isotopes, snowmelt and delivery to plants may vary. We suggest that a high proportional contribution of water derived from snowmelt, after relatively long and wet winters with high amounts of snowfall, can further lead to more negative $\delta D$ leaf wax values.

\subsection{Paleoclimatic interpretation of downcore data}

$\delta D$ and $\delta^{13} \mathrm{C}$ values from the Lake Karakuli sediment core suggest relatively warm and dry conditions between ca. 4 and $3.5 \mathrm{kyr} \mathrm{BP}$ (Fig. 7). $\delta^{13} \mathrm{C}$ values are highest for $\mathrm{C}_{24}$ during this interval, and even $\mathrm{C}_{28}$ shows slightly enriched values (>-30\% ; Fig. S3). Also, $\delta D$ shows maximum values during this episode. Even though an increased input from $\mathrm{C}_{4}$ plants or enhanced productivity of aquatic macrophytes could have biased $\delta D$ values slightly towards a more positive signal, we infer that this period probably was the warmest and driest in our studied time interval. After $3.5 \mathrm{kyr}$ a gradual cooling trend started (interrupted by a warmer and drier period between ca. 3.0 and $2.7 \mathrm{kyr} \mathrm{BP}$ ), peaking in coolest and wettest conditions around $2.5 \mathrm{kyr}$ BP. Between ca. 2.5 and $1.9 \mathrm{kyr} \mathrm{BP}$, we observe a reversal to a slightly warmer and drier climate, based on $\delta D$ evidence. We note that the $\delta^{13} \mathrm{C}$ values are rather variable and inconclusive in this core 


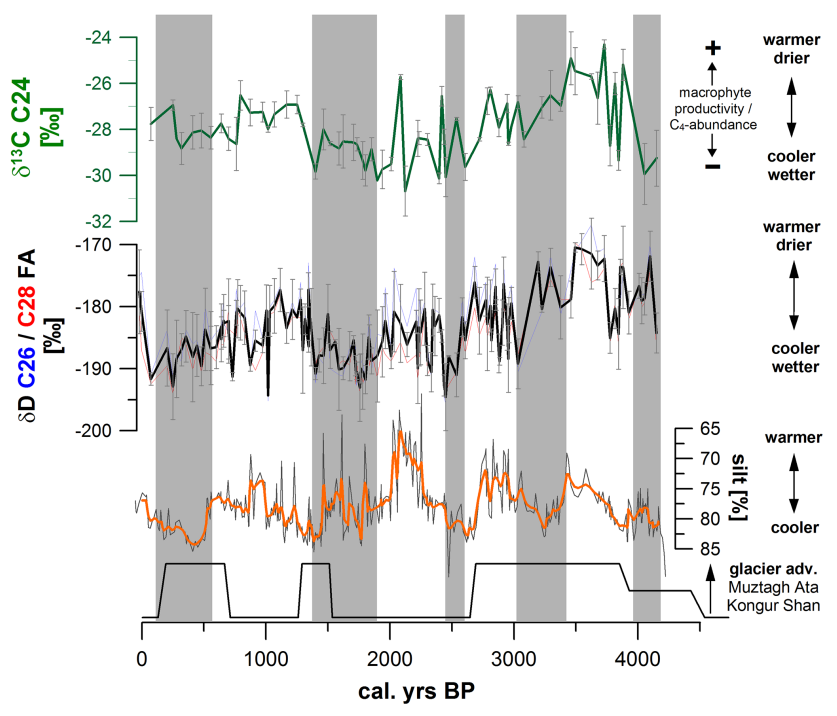

Figure 7. Summary of organic geochemical results from this study in the context of silt contents of the same sediment core (Liu et al., 2014; orange line: five-point weighted average) and data of local glacier advances inferred from ${ }^{10} \mathrm{Be}$ dating (Seong et al., 2009a; centers and widths of boxes mark the mean age and the error ranges of the events). Biomarker hydrogen isotopic data are presented as mean of triplicate measurements with $1 \sigma$ error bars for the $\mathrm{C}_{26}$ (blue line) and $\mathrm{C}_{28} n$-alkanoic acids (red line), as well as unweighted average of the two (thick black line). Shaded areas are relatively cool and wet episodes, based on leaf wax isotopic data.

section, and we observe an offset between $\delta D-\mathrm{C}_{26}$ and $\delta D$ $\mathrm{C}_{28}$ (these are normally within analytical error of each other). We hypothesize that warming influenced precipitation isotopes but that the change was not intense and stable enough to trigger a large-scale ecosystem response to be recorded in the $\delta^{13} \mathrm{C}$ values. Between ca. 1.9 and $1.4 \mathrm{kyr} \mathrm{BP}$, cool and wet conditions occurred again before returning to a warm and dry episode from ca. 1.4 to $0.6 \mathrm{kyr} \mathrm{BP}$ (possibly interrupted by a cooling event around $1 \mathrm{kyr} \mathrm{BP}$ ). The last $0.6 \mathrm{kyr}$ have been mainly cool and wet again, except for the last ca. 100 years, where the topmost three samples of the sediment core indicate another reversal to relatively warm and dry conditions.

Enhanced precipitation, rather than lower temperatures, has been argued to be the main driving force behind the growth of glaciers in Asian high-altitude regions (Seong et al., 2009b). The cool and wet episodes deduced from our organic geochemical record match reconstructed glacial advances at Mts Muztagh Ata and Kongur Shan relatively well. Based on ${ }^{10} \mathrm{Be}$ dating of erratic boulders, Seong et al. (2009a) estimated maximal glacial advances at $4.2 \pm 0.3,3.3 \pm 0.6$ and $1.4 \pm 0.1 \mathrm{kyr}$ and a few hundred years before present (Fig. 7). Further, the $\delta D$ data are in good agreement with silt contents in the same sediment core (Fig. 7). These have been interpreted as having been influenced by glacial input and thus higher contents indicating cooler and wetter conditions (Liu et al., 2014).
Our interpretation of lower $\delta D$ values indicating both relatively cool and wet conditions fits results from other late Holocene records in arid Central Asia well (Fig. 8c, e and g). The Little Ice Age (LIA) corresponds to the cool and humid period between 0.6 and 0.1 cal. ka BP at Lake Karakuli and has been well documented as a widely humid episode in arid Central Asia (paleoclimatic data compiled in Chen et al., 2010; Fig. 8c). For instance, the Guliya ice core, located ca. $630 \mathrm{~km}$ SE from Lake Karakuli, shows relatively high accumulation rates during that period (Fig. 8e), indicating that higher precipitation amounts and not just higher effective moisture (induced by decreased evaporation during cooler conditions) represented the main driving force behind, e.g., higher lake levels. This very much contrasts with the situation in eastern, monsoonal Asia, where many records show a relatively dry LIA due to a weakened summer monsoon (Chen et al., 2010, and references therein).

Similarly, a number of records have shown a pronounced warm and dry period during the Medieval Climate Anomaly (MCA; Fig. 8c, e; Chen et al., 2010; Lauterbach et al., 2014; Esper et al., 2002), also seen in our record from Late Karakuli. At ca. 1 cal. ka BP, we observe a ca. 100-year interruption of this event indicated by three samples with lower $\delta D$ values. Recently, Lei et al. (2014) observed a similar spike in carbonate $\delta^{18} \mathrm{O}$ values from Lake Sasi Kul, which is located ca. $190 \mathrm{~km}$ west of our study site (Fig. 8b). Thus, we hypothesize that this interruption was not just a local phenomenon. Warm and dry conditions during the MCA have also been observed at Kashgar (western Tarim Basin; just ca. $150 \mathrm{~km}$ north of Lake Karakuli; Zhao et al., 2012) and Lake Bangong Co on the western Tibetan Plateau (Gasse et al., 1996) and large Lake Karakul in the Tajik Pamir (Mischke et al., 2010).

Applying these findings to the complete record, we see fluctuating climatic conditions throughout the late Holocene with clearly identifiable warmer and drier and cooler and wetter episodes (Figs. 7 and 8). During the oldest section of our record (ca. 4.2-3.4 kyr BP), average conditions appear to have been warmer and drier than during the medieval period and today, followed by a general (even though non-continuous) cooling trend until ca. $2.4 \mathrm{kyr}$ BP. A cool and wet phase of roughly 1000 years starting at ca. $3.5 \mathrm{kyr}$ BP has been observed in numerous global climate records (Mayewski et al., 2004). At the nearby oasis of Kashgar, relatively wet conditions prevailed from ca. 4.0 until ca. $2.6 \mathrm{kyr}$ BP (Zhao et al., 2012). At the large Lake Karakul in Tajikistan, a rapid drop in TOC contents occurred at ca. 3.5 cal. ka BP, indicating a drop in lake productivity probably induced by low temperatures and eventually associated with shorter ice-free periods in the summer (Mischke et al., 2010; Fig. 8h). At Lake Balikun (northeastern Xinjiang), a reversal to wetter conditions occurred after a pronounced dry event lasting from 4.3 to $3.8 \mathrm{kyr}$ BP (An et al., 2012). In Lake Manas (northern Xinjiang), a wet episode was reconstructed for $4.5-2.5 \mathrm{kyr} \mathrm{BP}$, interrupted by a short dry period between 


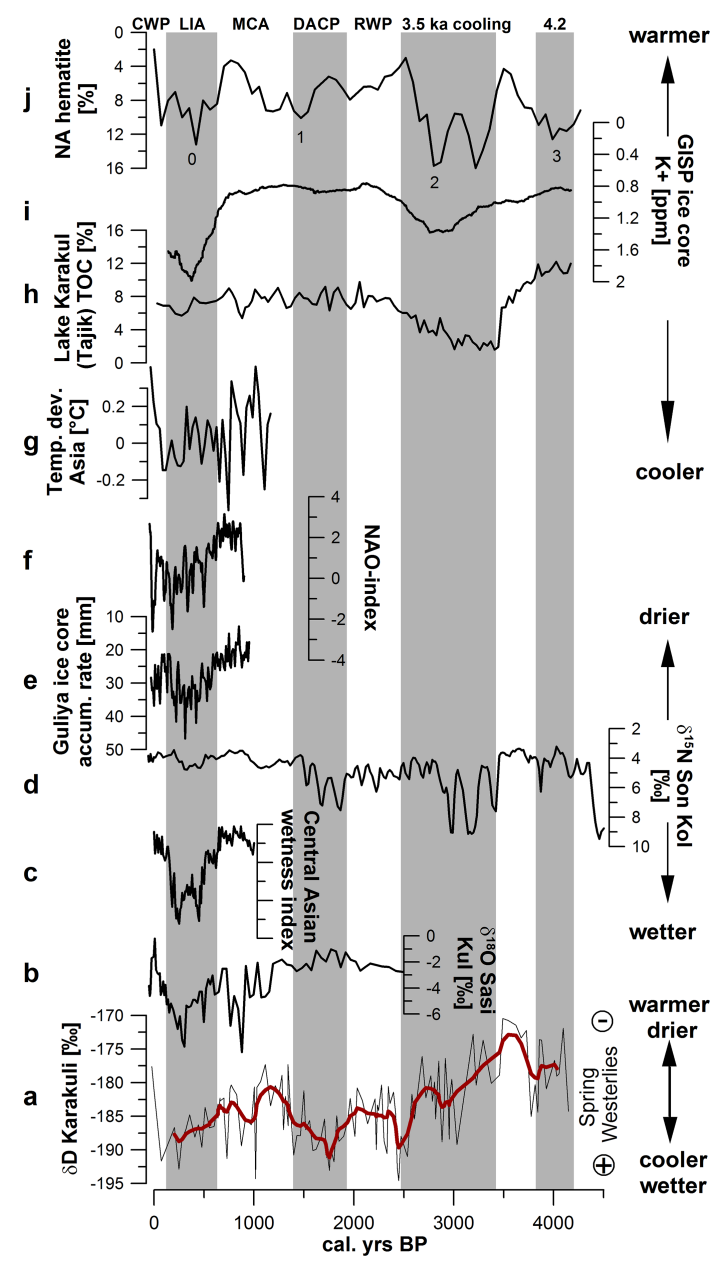

Figure 8. Comparison to local and northern hemispheric paleorecords. Shaded areas indicate relatively cool and wet episodes at Lake Karakuli; (a) $\delta D$ of $\mathrm{C}_{26}$ and $\mathrm{C}_{28} n$-alkanoic acids Lake Karakuli (this study); average values as in Fig. 8; red line: fivepoint weighted average. (b) $\delta^{18} \mathrm{O}$ Sasi Kul, Pamir, Tajikistan (Lei et al., 2014). (c) Central Asian wetness index (Chen et al., 2010). (d) $\delta^{15} \mathrm{~N}$ TN, Son Kol, Central Tien Shan, Kyrgyzstan (Lauterbach et al., 2014). (e) Guliya ice core accumulation rate (Thompson et al., 1997). (f) North Atlantic Oscillation index (Trouet et al., 2009). (g) 30-year average of compiled temperature deviations in Asia (Pages 2k Network, 2013). (h) TOC contents large Lake Karakul, Pamir, Tajikistan (Mischke et al., 2010). (i) $\mathrm{K}^{+}$GISP2 ice core (Mayewski et al., 1997). (j) North Atlantic (NA) hematite grains indicating northern hemispheric cooling events ("Bond events"; Bond et al., 2001).

3.8 and $3.5 \mathrm{kyr}$ BP (Rhodes et al., 1996). Low $\delta^{18} \mathrm{O}$ values in the Guliya ice core between 3.5 and $3.0 \mathrm{kyr} \mathrm{BP}$ also give evidence for low temperatures on the northwestern Tibetan Plateau (Thompson et al., 1997), while in the southern Tarim Basin, a rapid shift to wetter conditions at ca. $3.0 \mathrm{kyr}$ BP has been observed (Zhong et al., 2007).

After a ca. 500-year slight warming (ca. 2.4-1.9 kyr BP; synchronous with the Roman Warm Period, RWP), another reversal into cool and wet conditions occurred, peaking at ca. 1.8-1.6 kyr BP (often referred to as the Dark Ages Cool Period, DACP, or Migration Period). Both of these events have also been observed in the nearby Kashgar (Zhao et al., 2012). Afterwards the climatic trend gradually transitioned into the abovementioned warm period during the medieval period, followed by the LIA and the current warming period (CWP), the latter indicated by increased $\delta D$ values in the topmost three samples of the sediment core.

\subsection{Implications for Central Asian climate dynamics}

The sequence of relatively cool/wet and warm/dry episodes displays coherency with other Northern Hemisphere climate records. There is a similarity between the cyclicity of cooling events at Lake Karakuli, northern Atlantic ice-rafting events (Fig. 8j; Bond et al., 2001) and strengthening phases of the Siberian high (the anticyclonic high-pressure ridge over Siberia), the latter recorded by $\left[\mathrm{K}^{+}\right]$increases in the GISP2 (Greenland Ice Sheet Project) ice core between ca. 3.5-2.8 and 0.5-0.2 kyr BP (Fig. 8i; Mayewski et al., 1997). Further, throughout the last ca. 1000 years, $\delta D$ values of leaf waxes in Lake Karakuli are correlated with the mode of the North Atlantic Oscillation (NAO), showing more positive values during the current and medieval positive mode and more negative values during the LIA negative mode (Fig. 8f; Trouet et al., 2009).

The interplay between the dominant atmospheric circulation systems in Central Asia - the Siberian high, the midlatitude westerlies and, partly, the Indian summer monsoon - as well as orographic influences lead to complex climatic patterns. Trajectory studies in the modern atmosphere, as well as inventories of dust particles in ice cores, suggest the midlatitude westerlies as a primary source of moisture during winter and spring, with the North Atlantic, the Mediterranean, and the Black and Caspian seas as possible regions of origin (Lei et al., 2014; Seong et al., 2009a and b; Wu et al., 2008). The Siberian high delivers cool but also relatively dry air during winter. The absence of sea salt, i.e., in the Muztagh Ata ice core (Aizen et al., 2001; Seong et al., 2009b), provides further evidence for a minor importance of the Indian monsoon and for midlatitude westerlies and local convection to be the most important moisture sources during the summer.

Even though Lake Karakuli receives some moisture in spring (Fig. 4), regions which are located as close as $190 \mathrm{~km}$ westwards at a similar altitude, such as Lake Sasi Kul and other parts of the central and western Pamirs, receive much higher proportions and amounts of winter and spring precipitation (Lei et al., 2014; Miehe et al., 2001). Variations in strength and tracks of the westerlies and the related movement of the polar front (Machalett et al., 2008) could have influenced the amount of winter and spring moisture which has reached the Karakuli region in the past. Lei et al. (2014) suggested that during negative NAO modes (e.g., during the LIA) the storm tracks were moving further southwards, lead- 
ing to wetter conditions in the Mediterranean and higher amounts of moisture being transported into Central Asian areas of the same latitude. In contrast, other authors proposed a more complex interplay between the Eurasian and Pacific circulation systems on the basis of modeling data and a generally higher delivery of moisture into Central Asia during episodes of strengthened westerlies (i.e., positive NAO modes; Syed et al., 2010; Syed, 2011). Recently, a possible negative correlation between lower winter precipitation in the Mediterranean (positive NAO mode) and higher winter precipitation at Son Kol (central Tien Shan; ca. $400 \mathrm{~km}$ north of Lake Karakuli) was also suggested by Lauterbach et al. (2014) based on $\delta^{15} \mathrm{~N}$ data on total nitrogen (Fig. 8d).

Based on our data, we hypothesize that the relatively wet episodes recorded in our sediment core from Lake Karakuli were mainly caused by increased late-winter and spring precipitation derived from midlatitude westerlies. Cooling and wetting periods at $3.5 \mathrm{cal} . \mathrm{kaBP}$ and between 1.9 and $1.5 \mathrm{kyr}$ BP (DACP) are simultaneous with increased winter precipitation at Son Kol (Fig. 8d), indicating common climatic variations in the eastern Pamirs and the central Tien Shan. For the LIA, this connection is less pronounced. Instead, for the last ca. $1.5 \mathrm{kyr} \mathrm{BP}$, we see a close similarity to isotopic trends in the central Pamirs (Fig. 8b), which in turn drift apart between 1.5 and $2.5 \mathrm{kyr}$ BP. An explanation for this could be the increased influence of the significantly strengthened Siberian high during the LIA (Fig. 8i). This possibly either weakened the midlatitude westerlies or pushed their tracks further to the south, resulting in comparably drier conditions in more northern regions, such as the Tien Shan, but wetter conditions in the central and eastern Pamirs (Lei et al., 2014). A similar mechanism could explain the climatic pattern in the eastern Pamirs at present, with low winter and spring precipitation at low altitudes during the current positive NAO mode and westerlies penetrating more to the north, while the central Pamirs still receive high winter precipitation.

Despite a slight increase in total precipitation amount over the last 50 years in the dry areas of western China (Yao et al., 2012; Zhang and Cong, 2014), effective moisture in our study area has decreased due to rising temperatures. The two closed ponds and Lake Karakuli itself show clear geomorphological evidence for recent shrinking (field observations) and isotopic evidence for evaporative enrichment above meteoric waters (Table 1). This is in contrast to several endorheic lakes in Central Asia, whose lake levels are rising due to the currently increased meltwater input from receding glaciers (e.g., Bosten Lake; Wünnemann et al., 2006; or large Lake Karakul in Tajikistan, Mischke et al., 2010).

\section{Conclusions}

The biomarker isotopic record from Lake Karakuli, eastern Pamir, shows distinct episodes of relatively cool and wet as well as warmer and drier climates over the last 4200 years. Variations in the North Atlantic conditions and Siberian high both appear to show similarities with isotopic variability in our biomarker record, including notable excursions around $3.5 \mathrm{kyr}$, the MCA and the LIA. However, there are also indications of complex responses of regional climate, i.e., different responses between the western (e.g., western and central Pamir), eastern (e.g., eastern Pamir) and northern (e.g., Tien Shan) parts of Central Asia. This regional variability is thought to arise from changes in the dynamics and interplay of the large-scale atmospheric circulation systems involved, especially the strengths and pathways of the westerlies. Our data provide evidence that the transition between regions of summer-only and winter- and spring-dominated precipitation could have been a key factor for local climate in the past. They further show a rapid aridification in the eastern Pamir during the last $50-100$ years.

\section{The Supplement related to this article is available online at doi:10.5194/cp-11-619-2015-supplement.}

Acknowledgements. This work was supported by the German Academic Exchange Service (DAAD) postdoctoral fellowship to B. Aichner at the University of Southern California (USC) and by USC and the U.S. National Science Foundation (Grant No. 1002656) to S. Feakins for analytical costs. Funding from the Deutsche Forschungsgemeinschaft (DFG), the China Global Change Research Program (Grant No. 2012CB956101) and the National Science Foundation China (Grant No. 41072131) supported the fieldwork, the sample transport and the radiocarbon dating. We thank Hanno Meyer and Lutz Schoenicke (AWI Potsdam) for providing isotopic data of water samples. We are further grateful for help during field work (Jian Ni and Yang Bo), for assistance with core sampling (Yongbo Wang) and for analytical support at USC (Miguel Rincon).

Edited by: J. Guiot

\section{References}

Aichner, B., Herzschuh, U., and Wilkes, H.: Influence of aquatic macrophytes on stable carbon isotope signatures of sedimentary organic matter in lakes on the Tibetan Plateau, Org. Geochem., 41, 706-718, 2010a.

Aichner, B., Herzschuh, U., Wilkes, H., Mischke, S., and Zhang, C.: Biomarker and compound-specific carbon isotope evidence for changing environmental and carbon-limiting conditions at Koucha Lake, eastern Tibetan Plateau, J. Paleolimn., 43, 873899, 2010b.

Aichner, B., Herzschuh, U., Wilkes, H., Vieth, A., and Böhner, J.: $\delta D$ values of $n$-alkanes in Tibetan lake sediments and aquatic macrophytes a surface sediment study and application to a $16 \mathrm{ka}$ record from Lake Koucha, Org. Geochem., 41, 779-790, 2010 c. 
Aizen, E. M., Aizen, V. B., Melack, J. M., Nakamura, T., and Ohta, T.: Precipitation and atmospheric circulation patterns at midlatitudes of Asia, Int. J. Climatol., 21, 535-556, 2001.

Allen, E. D. and Spence, D. H. N.: The differential ability of aquatic plants to utilize the inorganic carbon supply in fresh water, New Phytol., 87, 269-283, 1981.

An, C. B., Feng, Z. D., and Barton, L.: Dry or humid? MidHolocene humidity changes in arid and semi-arid China, Quaternary Sci. Rev., 25, 351-361, 2006.

An, C. B., Lu, Y., Zhao, J., Tao, S., Dong, W., Li, H., Jin, M., and Wang, Z.: A high-resolution record of Holocene environmental and climatic changes from Lake Balikun (Xinjiang, China): Implications for central Asia, Holocene, 22, 43-52, 2012.

Araguás-Araguás, L., Froehlich, K., and Rozanski, K.: Stable isotope composition of precipitation over southeast Asia, J. Geophys. Res.-Atmos., 103, 28721-28742, 1998.

Blaauw, M. and Christen, J. A.: Flexible paleoclimate age-depth models using an autoregressive gamma process, Bayesian Anal., 6, 457-474, 2011.

Bond, G., Kromer, B., Beer, J., Muscheler, R., Evans, M., Showers, W., Hoffmann, S., Lotti-Bond, R., Hajdas, I., and Bonani, G.: Persistent solar influence on North Atlantic climate during the Holocene, Science, 294, 2130-2136, 2001.

Boomer, I., Wünnemann, B., Mackay, A. W., Austin, P., Sorrell, P., Reinhardt, C., Keyser, C., Guichard, F., and Fontugne, M.: Advances in understanding the late Holocene history of the Aral Sea region, Quatern. Int., 194, 79-90, 2009.

Bowen, G. J. and Revenaugh, J.: Interpolating the isotopic composition of modern meteoric precipitation, Water Resour. Res., 39, 1299-1311, 2003.

Chen, F. H., Yu, Z. C., Yang, M. L., Ito, E., Wang, S., Madsen, D. B., Huang, X., Zhao, Y., Sato, T., Birks, J. B., Boomer, I., Chen, J., An, C., and Wünnemann, B.: Holocene moisture evolution in arid central Asia and its out-of-phase relationship with Asian monsoon history, Quaternary Sci. Rev., 27, 351-364, 2008.

Chen, F. H., Chen J. H., Holmes, J. A., Boomer, I., Austin, P., Gates, J. B., Wang, N. L., Brooks, S. J., and Zhang, J. W.: Moisture changes over the last millennium in the arid central Asia: A review, synthesis and comparison with monsoon region, Quaternary Sci. Rev., 29, 1055-1068, 2010.

Cheng, H., Zhang, P. Z., Spötl, C., Edwards, R. L., Cai, Y. J., Zhang, D. Z., Sang, W. C., Tan, M., and An, Z. S.: The climatic cyclicity in semiarid-arid central Asia over the past 500000 years, Geophys. Res. Lett., 39, L01705, doi:10.1029/2011GL050202, 2012.

Chikaraishi, Y. and Naraoka, H.: $\delta 13 \mathrm{C}$ and $\delta D$ identification of sources of lipid biomarkers in sediments of Lake Haruna (Japan), Geochim. Cosmochim. Ac., 69, 3285-3297, 2005.

Dansgaard, W.: Stable isotopes in precipitation, Tellus, 16, 436468, 1964.

Duan, K., Yao, T., Wang, N. L., Tian, L. D., Xu, B. Q., and Wu, G. J.: Records of precipitation in the Muztag Ata ice core and its climate significance to glacier water resources, J. Glaciol. Geocryol., 29, 680-684, 2007.

Esper, J., Schweingruber, F. H., and Winiger, M.: 1300 years of climatic history for Western Central Asia inferred from tree-rings, Holocene, 12, 267-277, 2002.

Fan, L. L., Tang., L. S., Wu, L. F., Ma., J., and Li, Y.: The limited role of snow water in the growth and development of ephemeral plants in a cold desert, J. Veg. Sci., 25, 681-690, 2014.
Feakins, S. J. and Sessions, A. L.: Controls on the D/H ratios of plant leaf waxes from an arid ecosystem, Geochim. Cosmochim. Ac., 74, 2128-2141, 2010.

Feakins, S. J., Kirby, M. E., Cheetham, M. I., Ibarra, Y., and Zimmerman, S. R. H.: Fluctuation in leaf wax D/H ratio from a southern California lake records significant variability in isotopes in precipitation during the late Holocene, Org. Geochem., 66, 4859, 2014.

Ficken, K. J., Li, B., Swain, D. L., and Eglinton, G.: An n-alkane proxy for the sedimentary input of submerged/floating freshwater aquatic macrophytes, Org. Geochem., 31, 745-749, 2000.

Gasse, F., Fontes, J. C., VanCampo, E., and Wei, K.: Holocene environmental changes in Bangong Co basin (western Tibet), 4, Discussion and conclusions, Palaeogeog. Palaeoclim. Palaeoecol., 120, 79-92,1996.

Gat, J. R.: Oxygen and hydrogen isotopes in the hydrologic cycle, Annu. Rev. Earth Pl. Sci., 24, 225-262, 1996.

Günther, F., Aichner, B., Siegwolf, R., Xu, B.Q., Yao, T., and Gleixner, G.: A synthesis of hydrogen isotope variability and its hydrological significance at the Qinghai-Tibetan Plateau, Quatern. Int., 313-314, 3-16, 2013.

Herzschuh, U.: Paleo-moisture evolution in monsoonal Central Asia during the last 50000 years, Quaternary Sci. Rev., 25, 163-178, 2006.

Hourdin, F., Musat, I., Bony, S., Braconnot, P., Codron. F., Dufresne, J. L., Fairhead, L., Filiberti, M. A., Friedlingstein, P., Grandpeix, J. Y., Krinner, G., LeVan, P., Li, Z. X., and Lott, F.: The LMDZ4 general circulation model: Climate performance and sensitivity to parametrized physics with emphasis on tropical convection, Clim. Dyn., 27, 787-813, 2006.

Huang, X., Oberhänsli, H., von Suchodoletz, H., and Sorrell, P.: Dust deposition in the Aral Sea: Implications for changes in atmospheric circulation in central Asia during the past 2000 years, Quaternary Sci. Rev., 30, 3661-3674, 2011.

Kahmen, A., Hoffmann, B., Schefuß, E., Arndt, S. K., Cernusak, L. A., West, J. B., and Sachse, D.: Leaf water deuterium enrichment shapes leaf wax $n$-alkane $\delta D$ values of angiosperm plants II: observational evidence and global implications, Geochim. Cosmochim. Ac., 111, 50-63, 2013a.

Kahmen, A., Schefuss, E., and Sachse, D.: Leaf water deuterium enrichment shapes leaf wax $n$-alkane $\delta D$ values of angiosperm plants I: experimental evidence and mechanistic insights, Geochim. Cosmochim. Ac., 111, 39-49, 2013 b.

Kusch, S., Rethemeyer, J., Schefuß, E., and Mollenhauer, G.: Controls on the age of vascular plant biomarkers in Black Sea sediments, Geochim. Cosmochim. Ac., 74, 7031-7047, 2010.

Lauterbach, S., Witt, R., Plessen, B., Dulski, P., Prasad, S., Mingram, J., Gleixner, G., Hettler-Riedel, S., Stebich, M., Schnetger, B., Schwalb, A., and Schwarz, A.: Climatic imprint of the midlatitude Westerlies in the Central Tian Shan of Kyrgyzstan and teleconnections to North Atlantic climate variability during the last 6000 years, The Holocene, 24, 970-998, 2014.

Lee, J.-E. and Fung, I.: "Amount effect" of water isotopes and quantitative analysis of post-condensation processes, Hydrol. Processes, 22, 1-8, 2008.

Lee, J. E., Risi, C., Fung, I., Worden, J., Scheepmaker, R. A., Lintner, B., and Frankenberg, C.: Asian monsoon hydrometeorology from TES and SCIAMACHY water vapor isotope measurements and LMDZ simulations: Implications for speleothem 
climate record interpretation, J. Geophys. Res., 117, D15112, doi:10.1029/2011JD017133, 2012.

Lei, Y., Tian, L. D., Bird, B. W., Hou, J., Ding, L., Oimahmadov, I., and Gadoev, M.: A 2540-year record of moisture variations derived from lacustrine sediment (Sasikul Lake) on the Pamir Plateau, The Holocene, 24, 761-777, 2014.

Li, X., Zhao, K., Dodson, J., and Zhou, X.: Moisture dynamics in central Asia for the last 15 kyr: new evidence from Yili Valley, Xinjiang, NW China, Quaternary Sci. Rev., 30, 3457-3466, 2011.

Liu, X., Herzschuh, U., Shen, J., Jiang, Q., and Xiao, X.: Holocene environmental and climatic changes inferred from Wulungu Lake in northern Xinjiang, China, Quaternary Res.,70, 412-425, 2008.

Liu, X., Herzschuh, U., Wang, Y., Kuhn, G., and Yu, Z.: Glacier fluctuations of Muztagh Ata and temperature changes during the late Holocene in westernmost Tibetan Plateau, based on glaciolacustrine sediment records, Geophys. Res. Lett., 41, 6265-6273, 2014.

Liu, Z. H., Henderson, A. C. G., and Huang, Y. S.: Regional moisture source changes inferred from Late Holocene stable isotope records, Adv. Atmos. Sci., 25, 1021-1028, 2008.

Machalett, B., Oches, E. A., Frechen, M., Zöller, L., Hambach, U., Mavlyanova, N. G., Marković, S. B., and Endlicher, W.: Aeolian dust dynamics in central Asia during the Pleistocene: Driven by the long-term migration, seasonality, and permanency of the Asiatic polar front, Geochem. Geophys. Geosys. 9, Q08Q09, doi:10.1029/2007GC001938, 2008.

Mayewski, P. A., Meeker, L. D., Twickler, M. S., Whitlow S., Yang, Q., Lyons, W. B., and Prentice, M.: Major features and forcing of high-latitude northern hemisphere atmospheric circulation using a 110,000-year-long glaciochemical series, J. Geophys. Res., 102, 26345-26366, 1997.

Mathis, M., Sorrel, P., Klotz, S., Huang, X., and Oberhänsli, H.: Regional vegetation patterns at lake Son Kul reveal Holocene climatic variability in central Tien Shan (Kyrgyzstan, Central Asia), Quaternary Sci. Rev., 89, 169-185, 2014.

Mayewski, P. A., Rohling, E. E., Stager, J. C., Karlén, W., Maasch, K. A., Meeker, L. D., Meyerson, E. A., Gasse, F., van Kreveld, S., Holmgren, K., Lee-Thorp, J., Rosqvist, G., Rack, F., Staubwasser, M., Schneider, R. R., and Steig, E. J.: Holocene climate variability, Quaternary Res., 62, 243-255, 2004.

Miehe, G., Winiger, M., Böhner, J., and Yili, Z.: Climatic diagram map of high Asia, Purpose and concepts, Erdkunde, 55, 94-97, 2001

Mischke, S., Rajabov, I., Mustaeva, N., Zhang, C. J., Boomer, I., Brown, E. T., Andersen, N., Myrbo, A., Ito, E., and Schudack, M. E.: Modern hydrology and late Holocene history of Lake Karakul, eastern Pamirs (Tajikistan): A reconnaissance study, Palaeogeog. Palaeoclim. Palaeoecol., 289, 10-24, 2010.

Morill, C., Overpeck, J. T., and Cole, J. E.: A synthesis of abrupt changes in the Asian summer monsoon since the last deglaciation, Holocene, 13, 465-476, 2003.

Mügler, I., Gleixner, G., Günther, F., Mäusbacher, R., Daut, G., Schütt, B., Berking, J., Schwalb, A., Schwark, L., Xu, B., Yao, T., Zhu, L., and Yi, C.: A multi-proxy approach to reconstruct hydrological changes and Holocene climate development of Nam Co, Central Tibet, J. Paleolimn., 43, 625-648, 2010.
Narama, C.: Late Holocene variation of the raigorodskogo glacier and climate change in the Pamir-Alai, central Asia, Catena, 48, 21-37, 2002a.

Narama, C.: Glacier variations in Central Asia during the 20th century, J. Geogr., 111, 486-497, 2002b.

PAGES 2k Network.: Continental-scale temperature variability during the last two millennia, Nat. Geosci., 6, 339-346, doi:10.1038/ngeo1797, 2013.

Prins, H. B. A. and Elzenga, J. T. M.:Bicarbonate utilization: function and mechanism, Aquat. Bot., 34, 59-83, 1989.

Rach, O., Brauer, A., Wilkes, H., and Sachse, D.: Delayed hydrological response to Greenland cooling at the onset of the Younger Dryas in western Europe, Nat. Geosci., 7, 109-112, doi:10.1038/ngeo2053, 2014.

Rayner, N. A., Parker, D. E., Horton, E. B., Folland, C. K., Alexander, L. V., Rowell, D. P., Kent, E. C., and Kaplan, A.: Global analyses of sea surface temperature, sea ice, and night marine air temperature since the late nineteenth century, J. Geophys. Res., 108, 4407, doi:10.1029/2002JD002670, 2003.

Reimer, P. J., Baillie, M. G. L., Bard, E., Bayliss, A., Beck, J. W., Blackwell, P. G., Ramsey, C. B., Buck, C. E., Burr, G. S., and Edwards, R. L. E.: IntCal09 and Marine09 radiocarbon age calibration curves, 0-50000 years cal BP, Radiocarbon, 51, 1111-1150, 2009.

Rhodes, T. E., Gasse, F., Lin, R., Fontes, J. C., Wei, K., Bertrand, P., Gilbert, E., Mélières, F., Tucholka, P., and Cheng, Z. Y.: A late pleistocene-Holocene lacustrine record from Lake Manas, Zunggar (northern Xinjiang, western China), Palaeogeog. Palaeoclim. Palaeoecol., 120, 105-121, 1996.

Ricketts, R. D., Johnson, T. C., Brown, E. T., Rasmussen, K. A., and Romanovsky, V. V.: Holocene, paleolimnology of Lake IssykKul, Kyrgyzstan: Trace element and stable isotope composition of ostracodes, Palaeogeog. Palaeoclim. Palaeoecol., 176, 207227, 2001.

Risi, C., Bony, S., Vimeux, F., and Jouzel, J.: Water-stable isotopes in the LMDZ4 general circulation model: Model evaluation for present-day and past climates and applications to climatic interpretations of tropical isotopic records, J. Geophys. Res., 115, D12118, doi:10.1029/2009JD013255, 2010.

Risi, C., Noone, D., Worden, J., Frankenberg, C., Stiller, G., Kiefer, M., Funke, B., Walker, K., Bernath, P., Schneider, M., Wunch, D., Sherlock, V., Deutscher, N., Griffith, D., Wennberg, P.O., Strong, K., Smale, D., Mahieu, E., Barthlott, S., Hase, F., García, O., Notholt, J., Wameke, T., Toon, G., Sayres, D., Bony, S., Lee, J., Brown, D., Uemura, R., and Sturm, C.: Processevaluation of tropospheric humidity simulated by general circulation models using water vapor isotopologues: 1 . Comparison between models and observations, J. Geophys. Res., 117, D05303, doi:10.1029/2011JD016621, 2012a.

Risi, C., Noone, D., Worden, J., Frankenberg, C., Stiller, G., Kiefer, M., Funke, B., Walker, K., Bernath, P., Schneider, M., Bony, S., Lee, J., Brown, D., and Sturm, C.: Process-evaluation of tropospheric humidity simulated by general circulation models using water vapor isotopic observations: 2 . Using isotopic diagnostics to understand the mid and upper tropospheric moist bias in the tropics and subtropics, J. Geophys. Res., 117, D05304, doi:10.1029/2011JD016623, 2012b. 
Sachse, D., Billault, I., Bowen, G. J., Chikaraishi, Y., Dawson, T. E., Feakins, S. J., Freeman, K. H., Magill, C. R., McInerney, F. A., van der Meer, M. T. J., Polissar, P., Robins, R. J., Sachs, J. P., Schmidt, H.-L., Sessions, A. L., White, J. W. C., West, J. B., and Kahmen, A.: Molecular paleohydrology: Interpreting the hydrogen-isotopic composition of lipid biomarkers from photosynthesizing organisms, Annu. Rev. Earth Pl. Sci., 40, 221-249, 2012.

Sage, R. F., Kocacinar, F., and Kubien, D. S.: $\mathrm{C}_{4}$ photosynthesis and temperature, in: $\mathrm{C}_{4}$ Photosynthesis and Related $\mathrm{CO}_{2}$ Concentrating, Advances in Photosynthesis and Respiration Mechanisms, 32, Springer Netherlands, doi:10.1007/978-90-481-94070_10, 161-195, 2011.

Schefuss, E., Schouten, S., and Schneider, R.: Climatic controls on central African hydrology during the past 20000 years, Nature, 473, 1003-1006, 2005.

Seong, Y. B., Owen, L. A., Yi, C., and Finkel, R. C.: Quaternary glaciation of Muztag Ata and Kongur Shan: Evidence for glacier response to rapid climate changes throughout the Late Glacial and Holocene in westernmost Tibet, Geol. Soc. Am. Bull., 121, 348-365, 2009a.

Sessions, A. L., Burgoyne, T. W., and Hayes, J. M.: Correction of $\mathrm{H}_{3}$ contributions in hydrogen isotope ratio monitoring mass spectrometry, Anal. Chem., 73, 192-199, 2001.

Seong, Y. B., Owen, L. A., Yi, C. L., Finkel, R. C., and Schoehnbohm, L.: Geomorphology of anomalously high glaciated mountains at the northwestern end of Tibet: Muztag Ata and Kongur Shan, Geomorphology, 103, 227-250, 2009b.

Seth, A., Rauscher, S. A., Rojas, M., Giannini, A., and Camargo, S. J.: Enhanced spring convective barrier for monsoons in a warmer world? A letter, Climatic Change, 104, 403-414, 2011.

Smith, F. A. and Freeman, K. H.: Influence of physiology and climate on $\delta D$ of leaf wax $n$-alkanes from C3 and C4-grasses, Geochim. Cosmochimic. Ac., 70, 1172-1187, 2006.

Sorrel, P., Popescu, S. M., Klotz, S., Suc, J. P., and Oberhänsli, H.: Climate variability in the Aral Sea basin (Central Asia) during the late Holocene based on vegetation changes, Quaternary Res., 67, 357-370, 2007a.

Sorrel, P., Oberhänsli, H., Boroffka, N., Nourgaliev, D., Dulski, P., and Röhl, U.: Control of wind strength and frequency in the Aral Sea basin during the late Holocene, Quaternary Res., 67, 371382, $2007 b$.

Syed, F. S.: On the intra-seasonal to decadal climate variability over South-Asia, Dissertation, Department of Meteorology, Stockholm University, Sweden, 2011.

Syed, F. S., Giorgi, F., Pal, J. S., and Keay, K.: Regional climate model simulation of winter climate over Central-Southwest Asia, with emphasis on NAO and ENSO effects, Int. J. Climatol., 30, 220-235, 2010.

Tian, L., Yao, T., Li, Z., MacClune, K., Wu, G., Xu, B., Li, Y., Lu, A., and Shen, Y.: Recent rapid warming trend revealed from the isotopic record in Muztagata ice core, eastern Pamirs, J. Geophys. Res., 111, D13103, doi:10.1029/2005JD006249, 2006.

Tierney, J. E., Russell, J. M., Huang, Y. S., Sinninghe Damsté, J. S., Hopmans, E. C., and Cohen, A. S.: Northern hemisphere controls on tropical southeast African climate during the past 60000 years, Science, 322, 252-255, 2008.
Thompson, L. G.: Ice core evidence for climate change in the Tropics: Implications for our future, Quaternary Sci. Rev., 19, 19-35, 2000.

Thompson, L. G., Yao, T., Davis, M. E., Henderson, K. A., MosleyThompson, E., Lin, P.-N., Beer, J., Synal, H. A., Cole-Dai, J., and Bolzan, J. F.: Tropical climate instability: The last glacial cycle from a Qinghai-Tibetan ice core, Science, 276, 1821-1825, 1997.

Treydte, K. S., Schleser, G. H., Helle, G., Frank, D. C., Winiger, M., Haug, G., and Esper, J.: The twentieth century was the wettest period in northern Pakistan over the past millennium, Nature, 440, 1179-1182, 2006.

Trouet, V., Esper, J., Graham, N. E., Baker, A., Scourse, J. D., and Frank, D. C.: Persistent positive North Atlantic Oscillation mode dominated the Medieval Climate Anomaly, Science, 324, 78-80, 2009.

Uppala, S. M., Kållberg, P. W., Simmons, A. J., Andrae, U., Bechtold, V. D. C., Fiorino, M., Gibson, J. K., Haseler, J., Hernandez, A., Kelly, G. A., Li, X., Onogi, K., Saarinen, S., Sokka, N., Allan, R. P., Andersson, E., Arpe, K., Balmaseda, M. A., Beljaars, A. C. M., Berg, L. V. D., Bidlot, J., Bormann, N., Caires, S., Chevallier, F., Dethof, A., Dragosavac, M., Fisher, M., Fuentes, M., Hagemann, S., Hólm, E., Hoskins, B. J., Isaksen, L., Janssen, P. A. E. M., Jenne, R., Mcnally, A. P., Mahfouf, J.-F., Morcrette, J.-J., Rayner, N. A., Saunders, R. W., Simon, P., Sterl, A., Trenberth, K. E., Untch, A., Vasiljevic, D., Viterbo, P. and Woollen, J.: The ERA-40 re-analysis, Q. J. Roy. Meteor. Soc., 131, 29613012, 2005.

Wang, Z. and Liu, W.: Carbon chain length distribution in $n$-alkyl lipids: A process for evaluating source inputs to Lake Qinghai, Org. Geochem., 50, 36-43, 2012.

Wu, G. J., Yao, T. D., Xu, B. Q., Tian, L. D., Li, Z., and Duan, K. Q.: Seasonal variations of dust record in the Muztagata ice cores, Chinese Sci. Bull., 53, 2506-2512, 2008.

Wünnemann, B., Mischke, S., and Chen, F.: A Holocene sedimentary record from Bosten Lake, China, Palaeogeog. Palaeoclim. Palaeoecol., 234, 223-238, 2006.

Wünnemann, B., Demske, D., Tarasov, P., Kotlia, B. S., Reinhardt, C., Bloemendal, J., Diekmann, B., Hartmann, K., Krois, J., Riedel, F., and Arya, N.: Hydrological evolution during the last $15 \mathrm{kyr}$ in the Tso Kar lake basin (Ladakh, India), derived from geomorphological, sedimentological and palynological records, Quaternary Sci. Rev., 29, 1138-1155, 2010.

Yao, T., Thompson, L., Yang, W., Yu, W., Gao, Y., Guo, X., Yang, X., Duan, K., Zhao, H., Xu, B., Pu, J., Lu, A., Xiang, Y., Kattel, D. B., and Joswiak, D.: Different glacier status with atmospheric circulations in Tibetan Plateau and surroundings, Nat. Clim. Change, 2, 663-667, 2012.

Yao, T., Masson-Delmotte, V., Gao, J., Yu, W., Yang, X., Risi, C., Sturm, C., Werner, M., Zhao, H., He, Y., Ren, W., Tian, L., Shi, C., and Hou, S.: A review of climatic controls on $\delta^{18} \mathrm{O}$ in precipitation over the Tibetan Plateau: Observations and simulations, Rev. Geophys., 51, 525-548, 2013.

Zhang, X. and Cong, Z.: Trends of precipitation intensity and frequency in hydrological regions of China from 1956 to 2005, Global Planet. Change, 117, 40-51, 2014. 
Zhao, K., Li, X., Dodson, J., Atahan, P., Zhou, X., and Bertuch, F.: Climatic variations over the last $4000 \mathrm{cal}$ yr BP in the western margin of the Tarim Basin, Xinjiang, reconstructed from pollen data, Palaeogeog. Palaeoclim. Palaeoecol., 321-322, 1623, 2012.
Zhong, W., Xue, J. B., Shu, Q., and Wang, L. G.: Climatic change during the last 4000 years in the southern Tarim Basin, Xinjiang, northwest China, J. Quaternary Sci., 22, 659-665, 2007. 